\title{
Профілактика дисфункціональних маткових кровотеч у пубертатний період
}

\author{
Н.Є. Костинська', Г.Б. Костинський² \\ 'Київський міжнародний університет, Київ, Україна \\ ${ }^{2}$ Міжнародний європейський університет, Київ, Україна
}

Анотація. Надмірна крововтрата в результаті маткової кровотечі впливає на фізичне, емоційне, соціальне і матеріальне благополуччя жінки. Більш глибоке розуміння фармакотерапії маткової кровотечі, не пов'язаної зі структурними порушеннями матки, має велике значення, оскільки дозволяє обрати найбільш ефективний метод лікування. У якості препаратів, що зменшують крововтрату, купірують дисменорею, чинять протизапальну дію, поліпшують рівень здоров'я і якість життя, розглянуто препарати компанії «WALA» - Кальций Кверкус Глобулі велаті, Метеорік Айрон Глобулі велаті та Апіс/Беладона кум Меркурі.

Ключові слова: дисфункціональні маткові кровотечі, ювенільні кровотечі, менорагія, дисменорея, профілактика дисфункціональних маткових кровотеч, Кальций Кверкус Глобулі велаті, Метеорік Айрон Глобулі велаті, Апіс/Беладона кум Меркурі.

Дисфункціональні маткові кровотечі (ДМК) репродуктивного періоду становлять близько $30 \%$ всіх гінекологічних захворювань, що відмічають у віці 18-45 років. Причинами можуть бути порушення гормонального гомеостазу після абортів, при ендокринних, інфекційних захворюваннях, інтоксикаціях, стресах, прийомі деяких лікарських препаратів (наприклад похідних фенотіазину). Відомо, що легше попередити, ніж потім лікувати. Профілактичні заходи сьогодні недостатньо розроблені. Разом з тим в медичній практиці українських лікарів з'явилися засоби, які можуть бути ефективними для профілактики і лікування ДМК репродуктивного періоду, впливаючи на патогенез хвороби.

ДМК обумовлені порушенням функціонального стану системи гіпоталамус - гіпофіз - яєчники - надниркові залози, що регулює гормональну функцію яєчників. ДМК відмічають переважно у періоди становлення і в'янення репродуктивної системи: у період статевого дозрівання (ювенільні кровотечі) і в пременопаузі. Вони можуть виникати у репродуктивний період при стресах, інфекціях, інтоксикаціях і зазвичай мають ановуляторний характер. У їх патогенезі певна роль належить інфекційно-токсичному впливу на гіпоталамічні структури, які не досягли функціональної зрілості у підлітковий період, що регулюють функцію яєчників. Особливо несприятливий вплив тонзилогенної інфекції. Певну роль відіграють психічні травми, фізичні перевантаження, неправильне харчування (зокрема гіповітаміноз). Тож причин виникнення ДМК може бути багато.

У зв'язку з цим для профілактики ДМК насамперед мають велике значення заходи, спрямовані на оздоровлення організму: санація вогнищ інфекції (карієс зубів, тонзиліт та ін.), загартовування і заняття фізичною культурою (рухливі ігри, гімнастика, лижі, ковзани, плавання), повноцінне харчування з обмеженням жирної і солодкої їжі, вітамінотерапія у весняно-зимовий період. Профілактика ювенільних кровотеч включає загартовування з раннього віку, заняття фізичною культурою, повноцінне харчування, розумне чергування праці і відпочинку, попередження інфекційних хвороб, особливо ангіни, своєчасну санацію вогнищ інфекції.

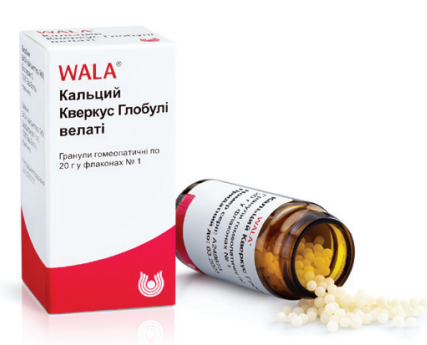

У якості неспецифічної профілактики рекомендують застосування кальцію. Значення кальцію для гомеостазу організму добре відоме. Однак застосування кальцію у матеріальних дозах (фармакологічні препарати, дієтичні добавки) може порушити баланс магнію, калію, вітаміну D, залежить від стану нирок і кишечнику. Застосування кальцію в потенційованому вигляді (технологія виготовлення гомеопатичних препаратів, препарат компанії «WALA» Кальций Кверкус Глобулі велаті) чинить регулюючу дію залежно від вихідного рівня кальцію у конкретної людини і мінерального обміну в цілому організмі. У потенційованому кальції зберігаються всі його ефекти. Кальцій регулює процеси, необхідні для здійснення передачі нервових імпульсів, скорочення скелетних і гладких м'язів, діяльності міокарда, формування кісткової тканини, згортання крові. Знижує проникність клітин і судинної стінки, запобігає розвитку запальних реакцій, підвищує стійкість організму до інфекцій і може значно посилювати фагоцитоз. Кальцій необхідний для нормальної функції ендокринних залоз, особливо в пубертатний період. Застосування потенційованного (гомеопатичного) кальцію не залежить від функції тонкого кишечнику і нирок, наявності або відсутності вітаміну D, pH, особливостей дієти і факторів, здатних зв'язувати $\mathrm{Ca}^{2+}$, зокрема від кількості білка крові. Кальцій ефективний при тривалих менструаціях з рясною кровотечею, дисменореї з головним болем, метрорагії. Дія кальцію посилює кверкус, який отримують із кори дуба.

Властивості кори дуба добре відомі в народній медицині. Кору дуба здавна застосовували при кровоточивості ясен, як протизапальний засіб різної етіології, при рясних менструаціях і кровотечах, при загальному ослабленні організму. У потенційованому вигляді кверкус зберігає ці властивості і набуває ще одної - поліпшення функції селезінки. Завдяки цьому кверкус бере участь у регуляції лімфопоезу (імунна і кровотворна функції), синтезу антитіл, обміну заліза. Важливо й те, що обидві складові препарату кальцій і кверкус виготовляються в препараті Кальций Кверкус Глобулі велаті за особливою технологією, так як рослинна речовина $\epsilon$ хорошим провідником мінеральної, сприяючи засвоєнню кальцію. Разом вони зміцнюють фізичне тіло, покращують обмінні процеси. У підлітковий період кальцій необхідний для росту і дозрівання репродуктивної системи. Таким чином, Кальций Кверкус Глобулі велаті зумовлює хорошу загальнозміцнювальну і кровоспинну дію і може бути використаний для профілактики ДМК.

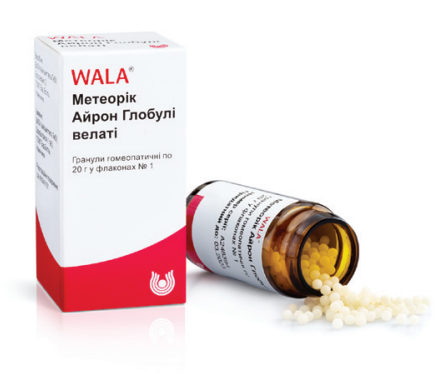

Іншим загальнозміцнювальним препаратом широкого спектру дії $\epsilon$ препарат компанії «WALA» Метеорік Айрон Глобулі велаті, що включає такі компоненти, як метеоритне залізо (Ferrum sidereum), фосфор і кварц.

Давня приказка говорить: «Той, хто не знає дії 
заліза, той не знає мистецтва зцілення». Залізо через функцію дихання регулює процеси асиміляції і дисиміляції, звільняючи венозну кров, навантажену альбумінами, від продуктів метаболізму. Залізо у вигляді дихальних ферментів - цитохромів необхідне для функціонування нервової тканини. 3 наявністю заліза пов'язана жовчоутворювальна діяльність печінки, яку можна розглядати як завершення процесу кровотворення. Жовч переварює жири і забезпечує організм енергією. Вміст заліза коливається залежно від віку. 3 нестачею заліза пов'язують високу захворюваність на анемію, застудні (бронхіт, пневмонія) та інфекційні захворювання. Метеоритне залізо у потенційованому вигляді ефективно підвищує адаптаційні можливості організму, включаючи процес одужання після перенесених захворювань, стресів, травм. Воно дуже ефективне при гіпохромній анемії і хлорозі у дівчаток підліткового віку. Включення фосфору і кварцу підсилює ефекти заліза і розширює можливості застосування препарату. Фосфор зміцнює нервову систему, судинну стінку, кістки. Він показаний при розумовому і фізичному виснаженні з головним болем $\mathrm{i}$ безсонням. Завдяки фосфору препарат Метеорік Айрон Глобулі велаті має дуже хороші показання до застосування у жінок з тенденцією до кровоточивості ясен, носових кровотеч, геморагічного діатезу, менорагії яскравою кров'ю зі згустками, міжменструальних кровотеч, анемії з вікарними кровотечами в анамнезі. Кварц (гірський кришталь, ангідрид кремнієвої кислоти) $\epsilon$ третьою складовою речовиною препарату. Кварц - це природна речовина кремнію. Кремній здавна застосовувався при різних захворюваннях, пов'язаних із порушенням функції сполучної тканини і клітинних елементів, що входять до їі складу (остеобласти, ретикулоендотеліальні клітини, фібробласти, клітини крові). Застосування кварцу у потенційованому вигляді активує фагоцитоз і захисну реакцію ретикулоендотелію, стимулюючи вироблення захисних антитіл, підвищує опірність до інфекцій. Кварц чинить протизапальну дію при хронічному запаленні придатків матки, перешкоджаючи утворенню спайок.

Таким чином, Метеорік Айрон Глобулі велаті $\epsilon$ незамінним засобом при реконвалесценції після багатьох хвороб і станів, попереджає порушення кровотворення і ДМК різної природи в осіб із кровотечами в анамнезі, підвищуючи в цілому імунітет, адаптацію до різних несприятливих факторів.

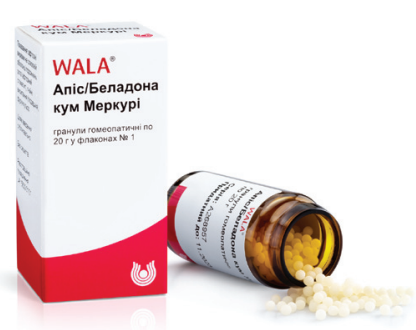

Для своєчасного лікування вогнищ інфекції, які $\epsilon$ провокаторами ДМК [1], рекомендується Апіс/Беладона кум Меркурі. Апіс і беладона у потенційованому вигляді чинять протизапальну і протинабрякову дію при будь-якому запальному процесі. Беладона діє при гострому запаленні і менорагії яскравою кров'ю з болем внизу живота, при дисменоpeï. Mercurius solubilis ефективний при запально-гнійних процесах, таких як фолікулярна ангіна, фурункульоз, гостре і хронічне запалення придатків, ендометрит із гнійними виділеннями, бартолініт і вульвовагініт. Таким чином, препарат ефективний

\footnotetext{
Відомості про авторів:

Костинська Наталія Євгенівна — доктор медичних наук, професор кафедри загальної медицини Київського міжнародного університету, Київ, Україна.

Костинський Григорій Борисович — доктор медичних наук, професор, завідувач кафедри анатомії, гістології та оперативної хірургії Міжнародного європейського університету, Київ, Україна.

Адреса для кореспонденції:

Костинський Григорій Борисович

03187, Київ, просп. Академіка Глушкова, 42В

E-mail: protos19@i.ua
}

при ключовій патогенетичній ланці кровотеч, асоційованих із функцією ендометрія, якою $є$ запалення. Своєчасне призначення препарату запобігає розвитку спайкової хвороби у маткових трубах, яєчниках, а також пов'язаному з цими процесами ДМК і безпліддя.

\section{Висновки}

1. Препарати компанії «WALA» Кальций Кверкус Глобулі велаті, Метеорік Айрон Глобулі велаті та Апіс/Беладона кум Меркурі ефективні для профілактики і лікування маткових кровотеч і ДМК без зміни структури матки.

2. Кальций Кверкус Глобулі велаті чинить хорошу загальнозміцнювальну і кровоспинну дію і може бути використаний для профілактики ДМК у жінок будь-якого віку, при порушенні менструального циклу у дівчаток у період статевого дозрівання.

3. Метеорік Айрон Глобулі велаті $\epsilon$ незамінним засобом при реконвалесценції після багатьох хвороб і станів, попереджає порушення кровотворення і ДМК різної природи у жінок 3 кровотечами, анемією в анамнезі, підвищуючи в цілому імунітет, адаптацію до різних несприятливих факторів.

4. Апіс/Беладона кум Меркурі ефективний при ключовій патогенетичній ланці кровотеч, асоційованих із функцією ендометрія, якою $€$ запалення. Своєчасне призначення препарату запобігає розвитку спайкової хвороби у маткових трубах, яєчниках, а також пов'язаних із цими процесами ДМК і безпліддя.

\section{Використана література/Reference:}

1. Chernukha G.E., llyina L.M. (2015) Inflammation — a biological basis for heavy menstrual bleeding, dysmenorrhea and CNS disorders. Integrated solution. Medical Council, XX:20-27. https://doi.org/10.21518/2079-701X-2015-XX-20-27. (In Rus.).

\section{Prevention of dysfunctional uterine bleeding during puberty}

\section{N.Ye. Kostynska', G.B. Kostynsky ${ }^{2}$}

${ }^{1}$ Kyiv International University, Kyiv, Ukraine

IInternational European University, Kyiv, Ukraine

Abstract. Excessive blood loss as a result of uterine bleeding affects a woman's physical, emotional, social and material wellbeing. A deeper understanding of the pharmacotherapy of uterine bleeding, not related to structural disorders of the uterus, is important because it allows to choose the most effective treatment. Calcium Quercus Globuli velati, Meteorik Airon Globuli velati and Apis/Belladonna cum Mercurio («WALA») were considered as drugs that reduce blood loss, relieve dysmenorrhea, have anti-inflammatory effect, improve health and quality of life.

Key words: dysfunctional uterine bleeding, juvenile bleeding, menorrhagia, dysmenorrhea, prevention of dysfunctional uterine bleeding, Calcium Quercus Globuli velati, Meteorik Airon Globuli velati, Apis/Belladonna cum Mercurio.

\section{Information about the authors:}

Kostynska Natalia Ye. - Doctor of Medical Sciences, Professor of the Department of General Medicine, Kyiv International University, Kyiv, Ukraine.

Kostynsky Hryhorii B. - Doctor of Medical Sciences, Professor, Head of the Department of Anatomy, Histology and Operative Surgery, International European University, Kyiv, Ukraine.

\section{Address for correspondence:}

Kostynsky Hryhorii B.

03187, Kyiv, Academician Glushkov ave, 42B

E-mail: protos19@i.ua 